\title{
Papel de la Intendencia de Verificación Especial, Ministerio Público y Contraloría General de Cuentas contra el Lavado de dinero
}

\section{Role of the Intendancy of Special Verification, Public Ministry and the Comptroller General of Accounts against money laundering}

Dora Patricia Soto Martinez

Universidad de San Carlos de Guatemala

dopasomar05@gmail.com

https://orcid.org/0000-0002-3435-3168

Recibido: $14 / 07 / 2021$

Aceptado: 01/09/2021

\section{Referencia del artículo}

Soto Martinez, D. P. (2021). Papel de la Intendencia de Verificación Especial, Ministerio Público y Contraloría General de Cuentas contra el Lavado de dinero. Revista Diversidad Científica, 1(1), 195-203.

DOI: https://doi.org/10.36314/diversidad.v1i1.21

\section{Resumen}

OBJETIVO: identificar la naturaleza, atribuciones, funciones y relación que tienen los entes fiscalizadores en su ramo para la prevención, control y sanción de actividades ilícitas. MÉTODO: a través de describir y comparar las funciones de los entes, se estableció como debería ser la comunicación para el fortalecimiento de una buena gobernanza. RESULTADOS: el lavado de dinero erosiona la integridad de las instituciones financieras de cualquier país, en el sentido que el dinero se canaliza en el sistema financiero nacional e internacional, aumentando el riesgo país, debilitando en paralelo la inversión nacional y extranjera, afectando la salud, la seguridad, la educación e integridad moral. CONCLUSIÓN: en Guatemala, los entes fiscalizadores encargados cada uno en su ramo y competencia de prevenir, controlar y sancionar el lavado de dinero u otros activos, son la Intendencia de Verificación Especial, el Ministerio Público y la Contraloría General de Cuentas.

Palabras clave: lavado de dinero, intendencia de verificación especial, ministerio público, contraloría general de cuentas 